\title{
Oxygen isotope analysis of Northwest Africa 12774 quenched angrite: Origin of olivine xenocrysts.
}

\author{
HIDEYUKI HAYASHI ${ }^{1}$, NAK KYU KIM ${ }^{2}$, HWAYOUNG \\ $\mathrm{KIM}^{2}$, CHANGKUN PARK ${ }^{2}$ AND TAKASHI MIKOUCHI ${ }^{3}$
}

${ }^{1}$ Dept. of Earth and Planet. Sci., The University of Tokyo, 73-1 Hongo, Bunkyo-ku, Tokyo 113-0033, Japan E-mail: h.hayashi@eps.s.u-tokyo.ac.jp ${ }^{2}$ Korea Polar Research Institute ${ }^{3}$ University Museum, The University of Tokyo

Angrite is one of the oldest basaltic achondrites in the early solar system showing either quenched or solowlycooled textures. Quenched angrites often contain Mg-rich olivine xenocrysts. They commonly exhibit relicted shapes, which implys that olivine xenocrysts in quenched angrites might come from other body(ies) (e.g.,[1]). We studied mineralogy and oxygen isotopic compositions of olivine phenocryst, olivine xenocryst and bulk sample of Northwest Africa (NWA) 12774 quenched angrite to discuss the origin of olivine xenocryst. Detailed mineralogical observation is in [2]. NWA 12774 shows a porphyritic texture with $c a .1 \mathrm{~mm}$ olivine and clinopyroxene grains set in the fine-grained groundmass. Only one olivine grain reaches $3 \mathrm{~mm}$. Some olivine grains (including $3 \mathrm{~mm}$ olivine grain) show $\mathrm{Mg}$-rich $\left(\mathrm{Fo}_{\geqq 88}\right)$ composition, whose core are $\mathrm{Cr}$-rich $\left(\mathrm{Cr}_{2} \mathrm{O}_{3}\right.$ of $\leqq 0.20$ $\mathrm{wt} \%)$ and Ca-poor ( $\mathrm{CaO}$ of $\leqq 0.35 \mathrm{wt} \%)$. These olivine grains are similar to those in Lewis Cliff 87051, which are considered to be xenocryst [3]. Thus we also consider them as xenocrysts. We gathered over $2 \mathrm{mg}$ of $1 \mathrm{~mm}$ olivines (mostly phenocrysts), $3 \mathrm{~mm}$ olvine (xenocryst), and bulk sample for oxygen isotopic analysis by IRMS (Instrumental details are found in [4]). Oxygen isotopic compositions are shown in Table 1. All NWA 12774 samples measured are on the AFL (Angrite Fractionation Line, [e.g., 5]) within the error range. This result suggests that olivine xenocrysts in NWA 12774 crystallized in the angrite parent body, not from other bodies.

Reference: [1] Jambon A. et al. (2008) Meteorit. \& Planet. Sci., 43, 1783-1795. [2] Hayashi H. et al. (2020) $51^{\text {st }}$ Annual Lunar \& Planet. Sci. Conference [3] Mikouchi T. et al. (1996) Proc. of NIPR Symp. Antarct. Meteorites, 9, 174188. [4] Kim N. K. et al. (2019) Rapid Commun. in Mass Spectrom., 33, 641-649. [5] Greenwood R. C. et al. (2005) Nature, 435, 916-918.

Table 1. Oxygen isotopic ratios \% (SEM)

\begin{tabular}{cccc}
\hline Sample of NWA 12774 & $\delta^{17} \mathrm{O}_{\mathrm{VSMOW}}$ & $\delta^{18} \mathrm{O}_{\mathrm{VSMOW}}$ & $\Delta^{17} \mathrm{O}$ \\
\hline Olivine (mostly pheno's) & $1.941(7)$ & $3.840(3)$ & $-0.044(7)$ \\
Olivine (xeno) & $1.892(6)$ & $3.764(3)$ & $-0.053(7)$ \\
Bulk sample 1 & $2.103(8)$ & $4.162(5)$ & $-0.051(7)$ \\
Bulk sample 2 & $2.107(7)$ & $4.162(4)$ & $-0.047(7)$ \\
\hline
\end{tabular}

